\title{
Anna Hajduk
}

Uniwersytet Ekonomiczny we Wrocławiu

e-mail: anka.hajduk@gmail.com

\section{WSPÓLNA PRZESTRZEŃ SZKOLNICTWA WYŻSZEGO W AZJI POLUDNIOWO-WSCHODNIEJ}

\section{COMMON SPACE OF HIGHER EDUCATION IN SOUTHEAST ASIA}

DOI: $10.15611 / \mathrm{e} 21.2017 .1 .01$

JEL Classification: A10

Streszczenie: Stowarzyszenie Narodów Azji Południowo-Wschodniej (ASEAN) zamierza stworzyć wspólną przestrzeń szkolnictwa wyższego w Azji Południowo-Wschodniej w ramach pogłębiania procesu integracyjnego. Jednakże zróżnicowany charakter systemów szkolnictwa wyższego w dziesięciu krajach członkowskich, wynikający z kontekstu historycznego i kulturowego, stał się istotnym wyzwaniem na drodze do harmonizacji. Celem niniejszej publikacji jest przegląd uwarunkowań i priorytetów działania szkolnictwa wyższego w państwach ASEAN pod kątem oceny możliwości utworzenia wspólnego obszaru szkolnictwa wyższego. Głównym źródłem informacji są raporty i publikacje dostępne na stronach internetowych zajmujących się problematyką szkolnictwa wyższego oraz organizacji rządowych i pozarządowych zaangażowanych $\mathrm{w}$ ten proces. Dobór źródeł wynika z dynamiki zmian poruszanej tematyki, a także chęci skorzystania z możliwie najaktualniejszych danych statystycznych.

Słowa kluczowe: szkolnictwo wyższe, ASEAN, procesy integracyjne, integracja, wspólna przestrzeń szkolnictwa wyższego w Azji Południowo-Wschodniej.

Summary: The Association of Southeast Asian Nations (ASEAN) is planning to create a Common Space of Higher Education in Southeast Asia within the framework of deepening the integration processes. However, the diverse nature of the higher education systems in all ten Member States, resulting from different historical backgrounds and cultural contexts, is proving to be a major challenge influencing the harmonization efforts. The purpose of this publication is to review current conditions and priorities of higher education systems in the ASEAN Member States in order to evaluate the likelihood of establishing the common area of higher education. The main sources of information are reports and publications available on the Internet concerning higher education as well as governmental and non-governmental organizations involved in the above-mentioned processes. The selection of sources reflects the most recent changes and trends in the field as well as the most current available statistics.

Keywords: higher education, ASEAN, integration processes, integration, Common Space of Higher Education in Southeast Asia. 


\section{Wstęp}

Kraje zrzeszone w Stowarzyszeniu Narodów Azji Południowo-Wschodniej (ASEAN) są obecnie siódmą potęgą gospodarczą na świecie z udziałem w światowym PKB na poziomie 25\% [The ASEAN Secretariat 2014, s. 1], liczbą ludności przekraczającą 600 milionów oraz trzecią pod względem wielkości siły roboczej, tuż za Indiami i Chinami. Idąc śladem Unii Europejskiej, z końcem 2015 roku cały region zintegrował się pod nazwą Wspólnoty Gospodarczej ASEAN (ASEAN Economic Community - AEC), co wiąże się ze swobodnym przepływem towarów, usług, inwestycji, osób i kapitałów ${ }^{1}$.

W ramach pogłębiania procesu integracyjnego zostanie stworzona wspólna przestrzeń szkolnictwa wyższego w Azji Południowo-Wschodniej (Common Space of Higher Education in Southeast Asia). Zidentyfikowano cztery główne priorytety umożliwiające harmonizację systemów edukacyjnych: zapewnienie jakości kształcenia, uznawalność dyplomów/kwalifikacji, mobilność studentów oraz system transferu ocen. Poszczególne rządy państw ASEAN zwiększyły nakłady na inwestycje w sferę nauki i edukacji na poziomie wyższym, którą ogółem tworzy 6500 instytucji i 12 milionów studentów w dziesięciu krajach. Podjęte inicjatywy zaczynają mieć również swoje przełożenie na reputację uczelni i miejsce w światowych rankingach [Yan Zhang 2013]. Dotyczy to głównie uczelni z Singapuru, Tajlandii i Malezji.

Celem artykułu jest przegląd uwarunkowań i priorytetów działania szkolnictwa wyższego w grupie państw ASEAN pod kątem oceny możliwości utworzenia wspólnego obszaru szkolnictwa wyższego. Głównym źródłem wykorzystanych informacji są raporty i publikacje dostępne na stronach internetowych zajmujących się problematyką szkolnictwa wyższego oraz witryny internetowe poszczególnych inicjatyw i organizacji. Dobór źródeł wynika przede wszystkim z dynamiki zmian poruszanej tematyki, a także chęci skorzystania z możliwie najaktualniejszych danych statystycznych. Artykuł w sposób obiektywny ukazuje proces integrowania istniejących zróżnicowanych systemów, likwidowania barier oraz powoływania nowych instytucji, niezbędnych do ustanowienia wspólnej przestrzeni szkolnictwa wyższego. Nie odnosi się do celowości i zasadności utworzenia wspólnej przestrzeni oraz efektywności jej działania, co będzie możliwe, gdy zacznie ona w pełni funkcjonować.

\section{Uwarunkowania historyczne rozwoju szkolnictwa wyższego w krajach ASEAN}

Państwa grupy ASEAN różnią się od siebie wielkością, poziomem rozwoju gospodarczego, religią, ustrojem politycznym jak również historią. Sytuacja i rozwój szkolnictwa wyższego w każdym z tych państw zależy od tych właśnie czynników.

${ }^{1}$ W skład stowarzyszenia ASEAN, którego celem jest utworzenie wspólnego rynku, weszły: Kambodża, Wietnam, Tajlandia, Malezja, Indonezja, Singapur, Laos, Mjanma, Filipiny i Brunei. 
Do zobrazowania istniejących różnic wystarczy zestawić ze sobą Singapur - jedno z najmniejszych państw świata, z Indonezją, którą tworzy ponad siedemnaście tysięcy wysp i pod względem liczby ludności plasuje się na czwartym miejscu na świecie. Singapur, Malezja oraz Tajlandia, postępując za globalnymi trendami, stały się państwami uprzemysłowionymi, natomiast Kambodża, Mjanma, Laos czy Wietnam znajdują się w okresie powolnej transformacji w tym kierunku od gospodarki opartej głównie na rolnictwie. Wśród tych słabiej rozwiniętych gospodarek szkolnictwo wyższe jest znacznie niedofinansowane, z niewykwalifikowanym zapleczem kadrowym oraz niedostosowanymi programami kształcenia do potrzeb rynku pracy. Zaskakujące jest również, że bogaty Singapur wydaje na szkolnictwo wyższe zaledwie 2,8\% PKB w porównaniu ze średnią w państwach członkowskich OECD, wynoszącą 5,2\% PKB [Matthews 2013]. Warto zauważyć, iż poza Tajlandią wszystkie pozostałe kraje członkowskie ASEAN mają w swej historii doświadczenia kolonizacji, co również wyjaśnia zasady funkcjonowania systemów szkolnictwa wyższego w tychże krajach [Pimpa 2011, s. 273]. W Tajlandii od momentu powstania pierwszego uniwersytetu, Chulalongkorn University, w 1917 roku wzorowano się głównie na modelu brytyjskim, zaś po drugiej wojnie światowej model amerykański zdominował tajskie szkolnictwo wyższe. Zupełnie inna jest historia akademicka w Kambodży. Wykorzystując potencjał elity naukowej wykształconej jeszcze przez francuskich kolonizatorów, w 1960 roku inaugurację swojej działalności rozpoczął The Royal University of Phenom Penh. W czasie przewrotu politycznego, który doprowadził do reżimu Czerwonych Kmerów w latach 1975-1978, 75\% wykładowców akademickich oraz 95\% studentów zostało wymordowanych lub wygnanych do innych krajów. Szacuje się, że po interwencji wietnamskiej w 1979 roku, w Kambodży pozostało mniej niż trzysta osób z wyższym wykształceniem. Większość z tych osób opuściła kraj, gdy tylko pojawiła się taka możliwość [Chet 2006, s. 3].

Mimo znaczących różnic w poszczególnych krajach w regionie, szkolnictwo wyższe w Azji Południowo-Wschodniej zmaga się z podobnymi problemami, jakimi są: zarządzanie skromnym budżetem, utrzymanie standardów w prowadzeniu działalności naukowej, zaspokojenie potrzeb kadry akademickiej i społecznych oczekiwań. Dodatkowym wyzwaniem stawianym przed niemal każdym krajem członkowskim ASEAN jest konieczność jednoczesnego przeprowadzania reform i nadążania za szybko zmieniającymi się trendami na poziomie globalnym [Lee, Healy 2006, s. 1-12].

\section{Popyt i podaż na usługi edukacyjne na poziomie wyższym}

Jednym z kluczowych i wciąż powtarzających się haseł w debacie o reformach w szkolnictwie wyższym w grupie państw ASEAN jest konieczność zwiększenia dostępu do samych instytucji i możliwość podjęcia w nich nauki. $Z$ jednej strony umasowienie edukacji na poziomie zarówno podstawowym, jak i średnim oraz wciąż rosnąca populacja w regionie spowodowały zwiększenie popytu na nauczanie 
na wyższych poziomach. W Wietnamie w 2010 roku na około 300 miejsc na państwowych uczelniach aplikowało 1,9 miliona kandydatów. Z drugiej jednak strony $52 \%$ studentów pochodziło z bogatych rodzin, a zaledwie $4 \%$ - z najuboższych [UNESCO Institute for Statistics 2014, s. 25], co obrazuje, w jaki sposób nierówności w sytuacji ekonomicznej czy miejsce zamieszkania decydują o możliwości kontynuowania edukacji. Do roku 1970 w Malezji był tylko jeden państwowy uniwersytet - University of Malaya, do którego studenci byli przyjmowani na podstawie egzaminów wstępnych. W znakomitej większości najlepszymi kandydatami z dziedzin technicznych byli Chińczycy ${ }^{2}$ zamieszkujący miasta, w przeciwieństwie do Malajów zamieszkujących głównie tereny wiejskie. Po zamieszkach na tle rasowym w 1969 roku rząd wprowadził zmiany, które miały podnieść poziom życia malezyjskiej ludności i jednocześnie zaprowadzić harmonię w społeczeństwie. Zdecydowano wówczas o podziale miejsc na uniwersytecie między Malajów i nie-Malajów w stosunku 55 do 45. Stworzono specjalną komisję egzaminacyjną, która przyznawała punkty za przynależność do konkretnej grupy etnicznej, miejsce zamieszkania, sytuację ekonomiczną oraz osiągnięcia naukowe. Do pewnego stopnia system ten osiągnął swój polityczny cel, ale był daleki od promowania ideałów jedności i wspólnoty. W Laosie również wydzielona jest konkretna liczba miejsc dla kandydatów z obszarów wiejskich. Często nie udaje się ich wykorzystać, gdyż kandydaci nie spełniają wstępnych wymagań pod względem merytorycznym. W Tajlandii aż 44\% uniwersytetów znajduje się w okolicach Bangkoku, co oznacza, że mieszkańcy stolicy lub jej aglomeracji mają zdecydowanie większy dostęp do tych instytucji. Dodatkowo aż 70\% tajskich studentów pochodzi z rodzin zamożnych. W raporcie Asian Development Bank, dotyczącym dostępu do edukacji, można znaleźć dość paradoksalną prawidłowość. Otóż: osoby ze zmarginalizowanej lub ubogiej społeczności rzadziej odnoszą sukces na egzaminach wstępnych na państwową uczelnię wyższą i są zmuszone do płacenia stosunkowo wysokiego czesnego na uczelniach prywatnych lub do zaprzestania edukacji. Ze względu na liczbę kandydatów w stosunku do bardzo ograniczonej liczby miejsc w filipińskich uczelniach państwowych o przyjęciu na studia decydują wyniki egzaminów wstępnych. Niezakwalifikowanie się oznacza brak możliwości kontynuowania edukacji bez wnoszenia opłat. Duża liczba prywatnych uczelni jest w stanie sprostać oczekiwaniom rynku. Jednak jakość kształcenia w prywatnej instytucji jest w pełni zależna od wysokości czesnego. Im lepsza uczelnia, tym wyższe opłaty. W konsekwencji ubożsi uczniowie, jeśli w ogóle podejmą naukę, to ich edukacja będzie stosunkowo niższej jakości [Asian Development Bank 2013, s. 15-17].

Pozytywne zmiany można zaobserwować w coraz równiejszym dostępie płci do szkolnictwa wyższego w regionie Azji Południowo-Wschodniej. Szczególnie w ciągu ostatniej dekady wzrosła liczba kobiet podejmujących dalszą edukację. W kra-

\footnotetext{
${ }^{2}$ Obywatele Malezji pochodzenia chińskiego, którzy posługują się językiem malajskim, zachowując wszelako kulturę chińską.
} 


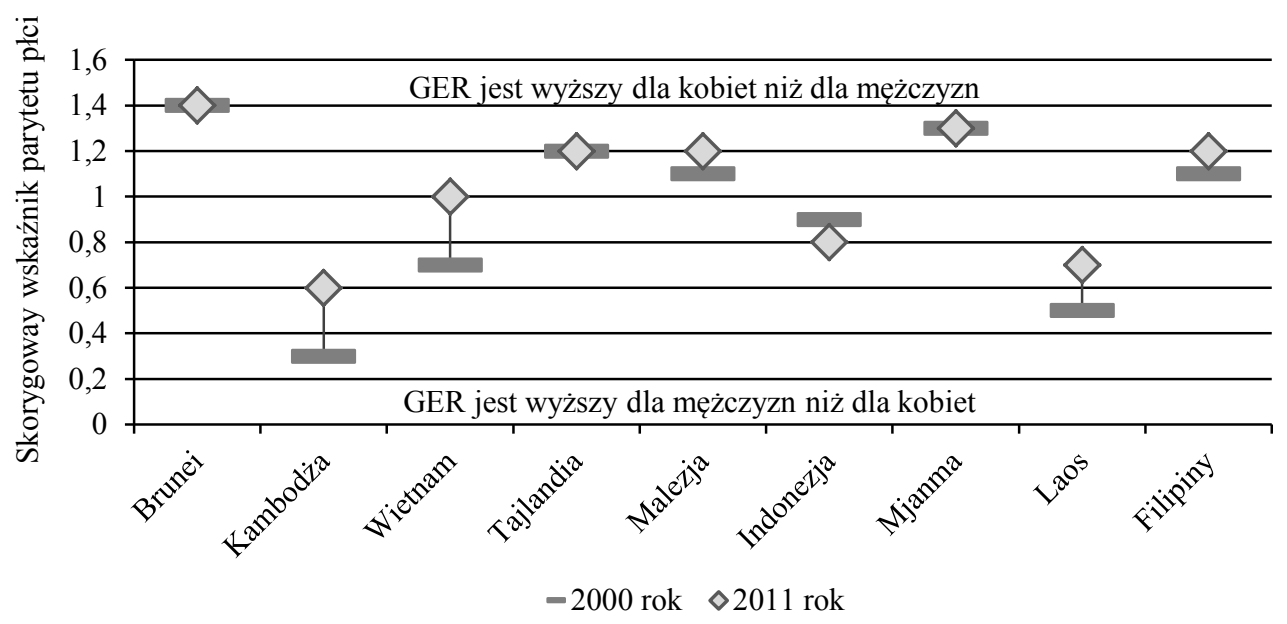

Rys. 1. Skorygowany wskaźnik parytetu płci w szkolnictwie wyższym dla współczynników skolaryzacji brutto w ASEAN

Źródło: opracowanie własne na podstawie danych [UNESCO Institute for Statistics 2014, s. 24].

jach, w których współczynnik skolaryzacji brutto (Gross Enrolment Ratio GER) dla kobiet jest zdecydowanie niższy niż dla mężczyzn, wskaźnik parytetu płci (Gender Parity Index - GPI) od 2004 roku przesunął się w kierunku parytetu $(0,97<$ GPI $>1,03)$, natomiast w krajach w których GER jest niższy dla mężczyzn sytuacja się praktycznie nie zmieniła, co przedstawia wykres poniżej [UNESCO Institute for Statistics 2014, s. 24-25].

\section{Dywersyfikacja branży edukacji na poziomie wyższym a zapewnienie jej jakości}

Zwiększone zapotrzebowanie na edukację na poziomie wyższym oraz wzrost jednostkowych kosztów spowodowały ogromne obciążenie finansowe dla wielu rządów, zmuszając je do restrukturyzacji istniejących systemów nadzorowania i finansowania szkolnictwa wyższego. Znany do niedawna podział uniwersytetów na państwowe (publiczne) i prywatne nie jest już tak oczywisty. Rządy poszczególnych państw, szukając oszczędności w budżetach, decydują się coraz częściej na cięcia w sferze akademickiej, zmuszając tym samym uczelnie do przyjęcia postawy aktywnego przedsiębiorstwa szukającego alternatywnych źródeł finansowania. Ciekawym przykładem może być Wietnam, w którym w 1988 roku powstały uczelnie niepubliczne (non-public) oraz półpubliczne (semi-public). Wśród niepublicznych pojawiły się uczelnie społeczne (people-funded institutions), tworzone przez pozarządowe lokalne społeczności, czy też stowarzyszenia zawodowe, mogące generować 
zysk (for profit) lub nie (non-profit). Władze wspierały rozwój takich uczelni przez przekazywanie gruntów czy też atrakcyjne ulgi podatkowe. W instytucjach półpublicznych infrastruktura jest własnością państwa, natomiast pozostałe koszty działalności, takie jak chociażby wynagrodzenia dla pracowników, muszą zostać pokryte $\mathrm{z}$ czesnego oraz ze sprzedaży usług edukacyjno-badawczych. Warto zauważyć, iż w 2005 roku nakłady uczelni półpublicznych na badania i rozwój wyniosły $0 \%$. W tym samym roku rząd podjął decyzję o zniesieniu uczelni półpublicznych oraz o uproszczeniu podziału instytucji szkolnictwa wyższego na publiczne i niepubliczne, jednocześnie, zachęcając uczelnie publiczne do naśladowania modelu zarządzania instytucji społecznych, czyli zwiększając udział czesnego oraz pozarządowych przychodów w budżecie instytucji w zamian za większą autonomię w wydatkach oraz w ofercie edukacyjnej. W rezultacie przyciągnęło to prywatne firmy do współtworzenia programów nauczania dla swoich przyszłych pracowników, skupiając się na specyficznych umiejętnościach i wiedzy, np. technicznej, inżynieryjnej. Wietnam otworzył się również na uczelnie zagraniczne, umożliwiając otwieranie pierwszych oddziałów-kampusów (branch campus) Royal Melbourne Institute of Technology czy też Hawaii University. W związku z przeprowadzonymi zmianami założono, że do 2010 roku 40\% ogólnej liczby studentów w Wietnamie będzie studiowało na uczelniach prywatnych. To dość ambitne założenie zostało najpierw przesunięte do 2012 roku, a następnie do 2020 roku. Odchodząc od sowieckiego modelu małych wyspecjalizowanych instytucji w kierunku dużych multidyscyplinarnych uniwersytetów, dokonano również podziału na uczelnie, które skupiają się na badaniach i rozwoju, oraz na kształcące profesjonalistów (vocational) w zakładanym stosunku procentowym 20 do 80 wszystkich studentów [Lim 2014, s. 129-131].

Od rozpoczętej w 1996 roku liberalizacji i umasowienia malezyjskiego szkolnictwa wyższego najbardziej widoczne są zmiany dotyczące liczby nowych dostawców wykształcenia wyższego oraz ich różnorodność ze względu na sposób finansowania. Do uczelni publicznych zalicza się zarówno uniwersytety państwowe, jak i kolegia, politechniki, akademie (public colleges) przygotowujące do określonego zawodu. Natomiast uczelnie niepubliczne to uczelnie prywatne, prywatne kolegia (private college), oddziały-kampusy zagranicznych uczelni, zdalne nauczanie/e-uniwersytet (virtual, distance education, e-university) oraz uniwersytet otwarty (open university). Malezyjski plan budowania pozycji jako centrum edukacyjne w regionie stworzył możliwości współpracy z instytucjami zagranicznymi, a także tworzenie publiczno-prywatnych partnerstw. W związku z tym można wyróżnić pięć rodzajów prywatnych uczelni wyższych ze względu na źródło finansowania:

1. Publiczna korporacja (public corporations), np. Malaysia Telecomunication jest właścicielem Multimedia University.

2. Spółka akcyjna (public listed companies), np. stworzony przez Sungei Wang Group Sunway College.

3. Partie polityczne rządu Frontu Narodowego (Barisan Nasional), np. Malaysian Indian Congress's Technical and Further Education (TAFE) College Seremban i Asian Institute of Science and Technology. 
4. Niezależne i samofinansujące się uczelnie prywatne.

5. Oddział-kampus uczelni zagranicznej, np. australijski Monash University [Sirat 2006, s. 108-110].

Obecność kampusów uczelni zagranicznych, głównie z Australii, Wielkiej Brytanii i Stanów Zjednoczonych zarówno w Wietnamie, jak i Malezji, wskazuje na powszechnie panujący trend do prowadzenia transgranicznej edukacji we wszystkich państwach grupy ASEAN. Dodatkowo można zaobserwować również intraregionalny przepływ usług edukacyjnych ponad granicami państw, np. Tajlandia i Wietnam goszczące oddziały uczelni z krajów bardziej doświadczonych w branży edukacyjnej - Malezji czy Singapuru. Rola prywatnych instytucji w regionie nie musi się ograniczać jedynie do zaspokojenia zapotrzebowania na wyższe wykształcenie wśród lokalnej społeczności. Może być motorem napędowym w podnoszeniu poziomu nauczania i jakości świadczonych usług naukowo-badawczych, zmianie oferowanych programów nauczania czy też samego języka nauczania, np. w Malezji w prywatnych instytucjach prowadzi się zajęcia w języku angielskim. Aby jednak rola szkół wyższych wpisywała się w strategie rozwoju, niezbędny jest monitoring ze strony odpowiednich jednostek do tego powołanych. Bieżąca kontrola jakości zarówno prywatnych, jak i publicznych uczelni jest utrudniona przez rozbudowaną machinę biurokratyczną, w której odpowiedzialność się po prostu rozmywa. W Kambodży poszczególne publiczne instytucje szkolnictwa wyższego nadzorowane są przez dziewięć różnych ministerstw, prywatne zaś przez jedno. Warto jednak zauważyć, że Kambodża, Malezja i Tajlandia, jako jedyne państwa w regionie, uchwaliły ustawy regulujące działalność prywatnych uczelni.

\section{Glocal}

Sytuacja demograficzna oraz niewystarczająca liczba miejsc na uczelniach wyższych w poszczególnych państwach ASEAN są niewątpliwie czynnikami zachęcającymi do podjęcia studiów poza granicami własnego kraju. Z zestawienia pięciu najczęściej wybieranych kierunków wynika (tab. 1), że głównie są to Australia oraz Stany Zjednoczone, ale tuż za nimi jest Tajlandia. Widoczne jest także zainteresowanie innymi państwami w regionie - Malezją, Indonezją czy Wietnamem.

Sytuacja ukazana $\mathrm{w}$ tabeli obrazuje tendencje do zmian w definicji międzynarodowego studenta, którym jest student glocal. Jest to dalej student z globalnymi aspiracjami (global), ale zdecydowany na podjęcie studiów na miejscu w regionie (local). Decyzja o wyborze lokalizacji uczelni w dużym stopniu zależy od sytuacji finansowej przyszłego studenta i jego rodziny. Bardzo zdolni uczniowie mają szanse na zdobycie stypendium. Tym mniej zdolnym naprzeciw wychodzi edukacja transgraniczna czy w przypadku innych państw ASEAN - intraregionalna. W przeciwieństwie do głównej siedziby danej uczelni wysokość czesnego jest proporcjonalna do możliwości lokalnego rynku, często wymagania związane ze znajomością 
Tabela 1. Zestawienie pięciu najpopularniejszych kierunków zagranicznych dla studentów z grupy państw ASEAN

\begin{tabular}{|c|c|c|c|c|c|}
\hline \multirow[t]{2}{*}{$\begin{array}{l}\text { Kraje } \\
\text { ASEAN }\end{array}$} & \multicolumn{5}{|c|}{$\begin{array}{l}\text { Pięć najpopularniejszych zagranicznych kierunków dla studentów z krajów ASEAN } \\
\qquad \begin{array}{l}\text { w } 2014 \text { roku } \\
\text { (w nawiasie podana jest liczba studentów) }\end{array}\end{array}$} \\
\hline & 1 & 2 & 3 & 4 & 5 \\
\hline Kambodża & $\begin{array}{l}\text { Tajlandia } \\
(1182)^{* *}\end{array}$ & $\begin{array}{l}\text { Australia } \\
(728)\end{array}$ & \begin{tabular}{|l} 
Francja \\
$(611)$
\end{tabular} & \begin{tabular}{|l} 
USA \\
$(527)^{* *}$
\end{tabular} & $\begin{array}{l}\text { Wietnam } \\
(381)^{* *}\end{array}$ \\
\hline Wietnam & $\begin{array}{l}\text { USA } \\
(19336)^{* *}\end{array}$ & $\begin{array}{l}\text { Australia } \\
(12898)\end{array}$ & \begin{tabular}{|l|} 
Japonia \\
$(6071)$
\end{tabular} & \begin{tabular}{|l|} 
Francja \\
$(5284)$
\end{tabular} & \begin{tabular}{|l|} 
Wielka Brytania \\
$(4236)$
\end{tabular} \\
\hline Tajlandia & $\begin{array}{l}\text { USA } \\
(7052)^{* *}\end{array}$ & $\begin{array}{l}\text { Wielka Brytania } \\
(6246)\end{array}$ & \begin{tabular}{|l} 
Australia \\
$(2933)$
\end{tabular} & \begin{tabular}{|l|} 
Japonia \\
$(2256)$
\end{tabular} & \begin{tabular}{|l|} 
Egipt \\
$(1958)$
\end{tabular} \\
\hline Malezja & $\begin{array}{l}\text { Wielka Brytania } \\
(15583)\end{array}$ & $\begin{array}{l}\text { Australia } \\
(15357)\end{array}$ & \begin{tabular}{|l|} 
USA \\
$(7858) * *$ \\
\end{tabular} & \begin{tabular}{|l|} 
Egipt \\
$(5067)$ \\
\end{tabular} & \begin{tabular}{|l|}
$\begin{array}{l}\text { Jordania } \\
(3071)^{* *}\end{array}$ \\
\end{tabular} \\
\hline Indonezja & $\begin{array}{l}\text { Australia } \\
\text { (9499) }\end{array}$ & $\begin{array}{l}\text { USA } \\
(8922) * *\end{array}$ & $\begin{array}{l}\text { Malezja } \\
(5700)^{* *}\end{array}$ & \begin{tabular}{|l|} 
Japonia \\
$(2387)$
\end{tabular} & \begin{tabular}{|l|} 
Egipt \\
$(2262)$
\end{tabular} \\
\hline Singapur & $\begin{array}{l}\text { Australia } \\
(8773)\end{array}$ & $\begin{array}{l}\text { Wielka Brytania } \\
(6774)\end{array}$ & $\begin{array}{l}\text { USA } \\
(4678) * *\end{array}$ & $\begin{array}{l}\text { Malezja } \\
(960)^{* *}\end{array}$ & $\begin{array}{l}\text { Kanada } \\
(399)^{*}\end{array}$ \\
\hline Mjanma & $\begin{array}{l}\text { Tajlandia } \\
(620)^{* *}\end{array}$ & $\begin{array}{l}\text { Japonia } \\
(1193)\end{array}$ & \begin{tabular}{|l|} 
USA \\
$(1209)^{* *}$
\end{tabular} & \begin{tabular}{|l} 
Australia \\
(739)
\end{tabular} & $\begin{array}{l}\text { Malezja } \\
(404)^{* *}\end{array}$ \\
\hline Laos & $\begin{array}{l}\text { Wietnam } \\
(1772)^{* *}\end{array}$ & $\begin{array}{l}\text { Tajlandia } \\
(793)^{* *}\end{array}$ & \begin{tabular}{|l}
$\begin{array}{l}\text { Australia } \\
(218)\end{array}$ \\
\end{tabular} & \begin{tabular}{|l|} 
Japonia \\
$(203)$
\end{tabular} & \begin{tabular}{|l|}
$\begin{array}{l}\text { Korea Płd. } \\
(75)^{*}\end{array}$ \\
\end{tabular} \\
\hline Filipiny & $\begin{array}{l}\text { USA } \\
(3037)^{* *}\end{array}$ & \begin{tabular}{|l} 
Australia \\
$(4177)$
\end{tabular} & \begin{tabular}{|l|} 
Wielka Brytania \\
$(698)$
\end{tabular} & \begin{tabular}{|l} 
Arabia Saudyjska \\
$(693)^{* *}$
\end{tabular} & \begin{tabular}{|l|} 
Japonia \\
$(488)$
\end{tabular} \\
\hline Brunei & $\begin{array}{l}\text { Wielka Brytania } \\
\text { (1932) }\end{array}$ & $\begin{array}{l}\text { Malezja } \\
(548)^{* *}\end{array}$ & $\begin{array}{l}\text { Australia } \\
\text { (484) }\end{array}$ & $\begin{array}{l}\text { Egipt } \\
(124)\end{array}$ & $\begin{array}{l}\text { Arabia Saudyjska } \\
(87)^{* *}\end{array}$ \\
\hline
\end{tabular}

* Rok 2013

** Rok 2015.

Źródło: opracowanie własne na postawie danych [Internet 10].

języka angielskiego czy warunków wstępnych są niższe, a możliwość zdobycia międzynarodowego doświadczenia oraz udziału w regionalnych inicjatywach gospodarczych dalej jest w ofercie. Wszystkie te zalety sprawiają, że studenci z grupy państw ASEAN są w światowej czołówce studentów glocal [Yan Zhang 2013].

\section{Wspólna przestrzeń szkolnictwa wyższego w Azji Południowo-Wschodniej}

Podpisanie Deklaracji bolońskiej 19 czerwca 1999 roku zapoczątkowało powstanie Europejskiego Obszaru Szkodnictwa Wyższego (European Higher Education Area - EHEA), którego celem jest zapewnienie jakości kształcenia oraz opracowanie kryteriów i metod oceny jakości, wprowadzenie punktowego systemu rozliczenia osiągnięć studentów ECTS, jak również promocja mobilności studentów i pracowników akademickich w krajach członkowskich. I choć zdania na temat dotychczasowych 
i przyszłych osiągnięć procesu bolońskiego są podzielone, nie ma wątpliwości, że stał się siłą napędową w konsolidowaniu systemów szkolnictwa wyższego w innych regionach na całym świecie [Knight 2013, s. 105-125].

Liczna grupa studentów glocal oraz integracja gospodarcza regionu Azji Południowo-Wschodniej spowodowały wzrost liczby inicjatyw wspierających przepływ kapitału ludzkiego. Jednakże zróżnicowany charakter systemów szkolnictwa wyższego $\mathrm{w}$ poszczególnych państwach, wynikający z uwarunkowań historycznych i kulturowych, stał się poważnym wyzwaniem na drodze ku harmonizacji struktur oraz tworzenia narzędzi wspomagających mobilność, aby osiągnąć zamierzone cele. Dlatego też, w przeciwieństwie do Europy i fundamentów EHEA, „harmonizacja oznaczać będzie porównywalność, a nie ustandaryzowanie lub ujednolicenie programów nauczania, stopni naukowych czy też systemów szkolnictwa wyższego" [Sirat, Azman, Abu Bakar 2014].

Przewidywane formy harmonizacji szkolnictwa wyższego w ASEAN to:

- Wymiana studentów - student spędza przynajmniej jeden rok akademicki na uczelni w innym kraju regionu.

- Studenci na wszystkich uczelniach w regionie będą otrzymywali wykształcenie takiej samej jakości.

- Absolwenci uczelni z jednego kraju będą mieli możliwość zatrudnienia w innym kraju regionu na podstawie zdobytych kwalifikacji.

- Międzynarodowe środowisko pracy.

- Ścisła współpraca studentów, wydziałów/instytutów, sektora przemysłowego w rozwijaniu nauki i nowych technologii.

- Dostęp dla osób dorosłych do kształcenia na poziomie szkolnictwa wyższego.

- Współpraca uczelnianych departamentów zajmujących się współpracą międzynarodową/internacjonalizacją (international offices) w całym regionie [Sirat, Azman, Abu Bakar 2014].

Zgodnie z ustalonym w 2009 roku planem stworzenia wspólnej przestrzeni szkolnictwa wyższego w Azji Południowo-Wschodniej, trzy instytucje zostały wskazane jako odpowiedzialne za zarządzanie procesami pogłębiania więzi w sferze szkolnictwa wyższego państw członkowskich ASEAN:

- Southeast Asian Ministers of Education Organization - Regional Centre for Higher Education and Development (SEAMEO-RIHED) - powstała na bazie istniejącej od 1965 roku SEAMEO, która reprezentując rządy państw Azji Południowo-Wschodniej, miała za zadanie promowanie współpracy w regionie w dziedzinie edukacji, nauki i kultury. SEAMEO-RIHED, z główną siedzibą w Bangkoku, koncentruje się przede wszystkim na wspieraniu efektywności, atrakcyjności i harmonizacji szkolnictwa wyższego ASEAN poprzez rozwój mechanizmów ułatwiających współpracę w dziedzinie szkolnictwa wyższego [Internet 7].

- ASEAN Plus Three (ASEAN +3) - powstała z inicjatywy rządu malezyjskiego w 1997 roku, swoje działania koncentruje na zacieśnianiu więzi pomiędzy 
ASEAN a Chińską Republiką Ludową, Japonią i Koreą Południową. W ramach ASEAN Plus Three opracowano plan rozwoju dla sektora edukacji na lata 2007-2017, który zakłada wdrożenie strategii związanych z zapewnieniem jakości kształcenia a także promocji mobilności [Internet 3].

- ASEAN Universities Network (AUN) - od 2007 roku jest kluczową instytucją wdrażającą społeczno-kulturalne inicjatywy w ASEAN. AUN inicjuje oraz realizuje działania promujące współpracę międzyuczelnianą $\mathrm{w}$ regionie przy jednoczesnym dążeniu do światowych standardów w szkolnictwie wyższym [Internet 6].

SEAMEO-RIHED, ASEAN Plus Three oraz AUN, dążąc do osiągnięcia załażonych priorytetów, w znacznym stopniu bazują na doświadczeniach EHEA, stosując podobne mechanizmy i narzędzia.

\subsection{Ramy zapewnienia jakości dla szkolnictwa wyższego w ASEAN}

W 2008 roku z inicjatywy SEAMEO-RIHED oraz Malaysian Quality Assurance Agency powstało ASEAN Quality Assurance Network (AQAN), jednocześnie angażujące agencje zajmujące sią jakością szkolnictwa wyższego w pozostałych krajach ASEAN. Wspólne prace nad budowaniem zaufania między poszczególnymi systemami edukacji, a w konsekwencji możliwością mobilności studentów oraz uznawalnością kwalifikacji doprowadziły do powstania w 2011 roku ram zapewnienia jakości dla szkolnictwa wyższego w ASEAN (ASEAN Quality Assurance Framework for Higher Education - AQAFHE). Jest to również narzędzie wspomagające systemy szkolnictwa wyższego w krajach ASEAN, które nie posiadają własnych struktur sprawujących nadzór nad jakością kształcenia [Internet 8].

Warto również wspomnieć o projekcie ASEAN-QA, finansowanym od 2011 roku przez rząd niemiecki, w który zaangażowane są instytucje europejskie takie, jak: Niemiecka Centrala Wymiany Akademickiej (DAAD), European Association for Quality Assurance (ENQA), German Rectors' Conference (HRK), a także reprezentujące ASEAN - AUN, AQAN, SEAMEO-RIHED. ASEAN-QA ma na celu wzmocnienie zdolności wewnętrznej i zewnętrznej kontroli jakości nauczania w instytucjach wyższych państw ASEAN przez dialog oraz wspólne szkolenia, mając jednocześnie na względzie różnice uwarunkowań obu regionów [Internet 4].

\subsection{Program międzynarodowej wymiany studentów w ASEAN}

Program międzynarodowej wymiany studentów w ASEAN (International Mobility for Students Programme - AIMS), powstały w 2010 roku na bazie wcześniejszego programu wymiany studentów pomiędzy Malezją, Indonezją i Tajlandią, tzw. M-I-T, do końca 2014 roku zachęcił 1200 studentów z 7 uczestniczących krajów (Malezja, Indonezja, Tajlandia, Wietnam, Brunei, Filipiny i Japonia) do wyjazdu na część studiów na jednej z uczelni partnerskich w regionie. Wymiana studentów odbywa się 
niemal wyłącznie na poziomie studiów pierwszego stopnia (undergraduate), a wsparcie finansowe pochodzi z budżetu państwa wysyłającego. Z tabeli 2 wyraźnie wynika wzrost zainteresowania AIMS ze strony zarówno studentów, jak i państw $\mathrm{w}$ regionie.

Tabela 2. Dynamika zmian w AIMS

\begin{tabular}{|l|l|l|}
\hline \multicolumn{1}{|c|}{2011} & \multicolumn{1}{c|}{2013} & \multicolumn{1}{c|}{2015 (prognoza) } \\
\hline 150 studentów & 300 studentów & 500 studentów \\
\hline 5 dziedzin nauki & 7 dziedzin nauki & 10 dziedzin nauki \\
\hline 3 kraje & 5 krajów & 10 krajów \\
\hline
\end{tabular}

Źródło: [Internet 12].

Bez wątpienia AIMS wpływa pozytywnie na poszczególne jednostki przez zrozumienie kulturowe regionu, a dla uczelni jest strategicznym narzędziem poszukiwania nowych możliwości współpracy oraz pogłębiania tych istniejących. Nie wszystkie uczelnie z partycypujących krajów mogą włączyć się do programu wymiany studentów. Wymogami są czołowa pozycja danej instytucji w rankingach w celu zapewnienia jakości nauczania oraz wdrożony system transferu ocen. Obecnie w AIMS bierze udział 61 uczelni wyższych, oferując możliwość wyjazdu dla studentów z najpopularniejszych kierunków w regionie ASEAN: turystyka i rekreacja (Hospitality and Tourism), rolnictwo (Agriculture), filologia (Language and Culture), handel zagraniczny (International Business), technologia żywienia (Food Science and Technology), zarządzanie produkcją (Engineering Economics), zarządzanie zasobami naturalnymi (Environmental Science and Management), oceanografia (Biodiversity and Marine Science) [SEAMEO RIHED Annual Report..., s. 13].

\subsection{Ramowa struktura kwalifikacji w ASEAN}

Od końca 2014 roku ramowa struktura kwalifikacji w ASEAN (ASEAN Qualifications Reference Framework - AQRF) funkcjonuje jako wspólne narzędzie umożliwiające uznawalność dyplomów oraz kwalifikacji między krajami członkowskimi ASEAN. AQFR ma nie tylko znaczenie dla promocji mobilności między uczelniami wyższymi, ale przede wszystkim dla jakości nauczania i mobilności wykwalifikowanych pracowników. W dłuższym okresie przyczyni się to do podniesienia liczby i jakości zasobów ludzkich, tak niezbędnych do zapewnienia dynamicznie rozwijającej się, wspólnej gospodarki państw ASEAN. Zwracając uwagę na fakt, że państwa członkowskie są na różnych etapach rozwoju, oczekuje się, że każdy kraj będzie dobrowolnie wdrażać AQFR w ramach swoich możliwości, lecz najpóźniej stanie się to do 2018 roku.

ASEAN otrzymał wsparcie w związku z tworzeniem AQFR ze strony zarówno Unii Europejskiej, jak i porozumienia zawartego z Australią i Nową Zelandią: 
- ASEAN-Australia-New Zealand Free Trade Area (AANZFTA) od 2010 roku w ramach projektu szkoleniowego w dziedzinie edukacji „Capacity Building for National Qualifications Framework” wypracowuje wzajemną porównywalność krajowych ram kwalifikacji na podstawie wspólnych ram odniesienia. Ustanowienie porównywalnych ram odniesienia zbuduje większe zaufanie w standardy nauczania i skutkować będzie swobodniejszym czasowym przepływem studentów i dostawców usług w dziedzinie szkolnictwa wyższego [Internet 1].

- SHARE jest to projekt finansowany z Unii Europejskiej, zarządzany przez British Council, DAAD, EP-Nuffic, Campus France, ENQA i European University Association (EUA) na lata 2015-2018. Poprzez dialog i wymianę doświadczeń z azjatyckimi partnerami docelowo skorzystać na tej inicjatywie mają studenci jako odbiorcy coraz wyższych jakościowo usług edukacyjnych, którzy jako absolwenci będą w przyszłości atrakcyjni dla pracodawców na rynku pracy. Nadrzędnym celem SHARE jest wsparcie ASEAN przy umiędzynarodawianiu i harmonizacji szkolnictwa wyższego oraz tworzenie trwałych korzyści wynikających z dalszej współpracy UE z AEC [Internet 9].

\subsection{System transferu punktów w ASEAN}

System transferu punktów w ASEAN (ASEAN Credit Transfer System - ACTS) został zainicjowany przez AUN jako narzędzie służące do transferu osiągnięć studentów między uczelnią wysyłającą i przyjmującą przy wymianie studenckiej w ASEAN. ACTS jest zarządzany przez AUN-ACTS Secretariat, który swoją siedzibę ma w Uniwersytecie Indonezyjskim (Universitas Indonesia). ACTS, jako wsparcie dla AIMS, jednocześnie promujące mobilność wśród studentów w regionie, nie wymaga wprowadzania zmian w systemie oceniania partycypujących państw oraz poszczególnych uczelni. Jego zasadniczym założeniem jest wypracowanie wspólnego systemu konwersji ocen bądź punktów.

W ramach projektu SHARE Campus France planuje zapewnić wsparcie w umacnianiu systemu ACTS przy jednoczesnym budowaniu systemu transferu ocen/punktów, ASEAN-EU Credit Transfer System (AECTS), ułatwiającego przyszłą wymianę studentów między ASEAN a Unią Europejską [Internet 2].

Mimo że ACTS istnieje od 2010 roku, do tej pory jedynie 32 uczelnie z dziesięciu krajów partnerskich dołączyły do tej inicjatywy. Drugim konkurencyjnym narzędziem, mającym za zadanie wspieranie mobilności w Azji, jest projekt o nazwie University Credit Transfer System (UCTS), stworzony przez pozarządowy związek reprezentujący azjatyckie szkolnictwo wyższe University Mobility in Asia and the Pacific (UMAP). Brak finansowego wsparcia i zrozumienia działania samego narzędzia sprawił, że UCTS nie odniósł większego sukcesu [Sirat, Azman, Abu Bakar 2014]. Za jedną $z$ głównych przeszkód w rozwoju mobilności studentów w ASEAN uważa się właśnie mnogość narzędzi transferu osiągnięć. 


\section{Wyzwania i konkluzje}

Tendencja do harmonizacji szkolnictwa wyższego w ASEAN wydaje się prawidłowa. Wspólnie podjęte inicjatywy stanowią solidne podstawy dalszego procesu integracyjnego. Sygnatariusze ASEAN uznają potrzebę stworzenia wspólnego, ale - co warto podkreślić - nie identycznego czy też ustandaryzowanego obszaru edukacji i nauki, który ułatwiłby porównywalność osiągnięć, a w konsekwencji mobilność studentów i pracowników. Jednak uwarunkowania historyczne oraz różnice kulturowe, językowe i religijne w poszczególnych państwach sprzyjają powstawaniu problemów podczas pogłębiania współpracy. Studenci zaangażowani w programy mobilnościowe mogą również stanąć w obliczu problemów dostosowawczych w odniesieniu do jakości kształcenia, nieporównywalności programów nauczania, a co za tym idzie - uzyskanych rezultatów czy różnorodności językowo-kulturowej. Koniecznością jest zatem pokonanie bariery języka i komunikacji, które zawsze były problemem w krajach Azji Południowo-Wschodniej, przez upowszechnienie użycia języka angielskiego na uczelniach wyższych. W kontekście współpracy nad jakością szkolnictwa wyższego w regionie nadal istnieje kilka przeszkód strukturalnych; najważniejszymi są problemy w dysproporcji rozwoju krajowych mechanizmów zapewniających jakość kształcenia oraz ułomności we wzajemnym zrozumieniu i tworzeniu powiązań między instytucjami z różnych krajów. W zasadniczy sposób przyczynia się to do nieskuteczności AQAN w całym regionie, a w następstwie wpływa na brak gwarancji transferu ocen między poszczególnymi systemami edukacyjnymi. Konieczna jest dalsza praca nad budowaniem wzajemnego zaufania oraz przejrzystości i zrozumienia mechanizmów kontroli jakości w innych krajach regionu. Bez wątpienia zaś sukcesem jest wspólne wypracowanie AQRF w obliczu wyzwania, jakim jest zachowanie autonomii lokalnych i krajowych wymogów nadawania stopni naukowych i przyznawania kwalifikacji zawodowych.

Stworzenie wspólnej przestrzeni szkolnictwa wyższego w Azji Południowo-Wschodniej przy założeniu harmonizacji, czyli wypracowywania pewnych kompromisów między dziesięcioma różnorodnymi systemami szkolnictwa wyższego, wymaga nie lada determinacji. Pełne zaangażowanie jest konieczne nie tylko ze strony samych rozgrywających, czyli SEAMEO-RIHED, ASEAN +3 , AUN i rządów poszczególnych państw, ale przede wszystkim ze strony instytucji szkolnictwa wyższego oraz całej społeczności ASEAN, bo to będzie ostateczna grupa odbiorców decydująca o powodzeniu tego przedsięwzięcia.

\section{Literatura}

Asian Development Bank, 2013, Access without Equity. Finding a Better Balance in Higher Education in Asia, http://www.adb.org/sites/default/files/publication/29769/access-without-equity.pdf (26.08.2015).

Chet C., 2006, Cambodia, [w:] Asia Pacific Programme of Educational Innovation for Development, UNESCO, Bangkok, Higher Education in South-East Asia, UNESCO Bangkok, Bangkok. 
Knight J., 2013, A Model for the Regionalization of Higher Education: The Role and Contribution of Tuning, [w:] Tuning Journal for Higher Education, Ryan P.D. (red.), no. 1, University of Deusto, http://www.tuningjournal.org/issue/view/1 (8.11.2015).

Lee M.N.N., Healy S., 2006, Higher Education in South-East Asia: An Overview, [w:] Asia Pacific Programme of Educational Innovation for Development, Higher Education in South-East Asia, UNESCO, Bangkok.

Lim D., 2014, Economic Growth and Employment in Vietnam, Routledge.

Matthews D., 2013, No Sleep for Singapore's Universities, Times Higher Education, https://www. timeshighereducation.com/features/no-sleep-for-singapores-universities/2009064.article (15.04.2015).

Pimpa N., 2011, Strategies for Higher Education Reform in Thailand, [w:] Higher Education in the Asia Pacific. Strategic Responses to Globalization, Higher Education Dynamics, Marginson S., Kaur S., Sawir E. (red.), vol. 36, Springer.

SEAMEO RIHED Annual Report 2014-2015, http://www.rihed.seameo.org/wp-content/uploads/ 2015/09/Annual-Report-2014-2015.pdf (15.11.2015).

Sirat M., 2006, Malaysia, [w:] Asia Pacific Programme of Educational Innovation for Development, UNESCO, Higher Education in South-East Asia, Bangkok.

Sirat M., Azman N., Abu Bakar A., 2014, Towards Harmonization of Higher Education in Southeast Asia: Malaysia's Perspective, Inside Higher Ed, https://www.insidehighered.com/blogs/globalhighered/towards-harmonization-higher-education-southeast-asia\#ixzz339fdDrY5 (8.11.2015).

The ASEAN Secretariat, 2014, ASEAN Community in Figures - Special Edition 2014: A Closer Look at Trade Performance and Dependency, and Investment, http://www.asean.org/images/pdf/2014 upload/ACIF\%20Special\%20Edition\%202014_web.pdf (5.04.2015).

UNESCO Institute for Statistics, 2014, Higher Education in Asia: Expanding Out, Expanding In. The rise of graduate education and university research, UNESCO-UIS, http://www.uis.unesco.org/ Library/Documents/higher-education-asia-graduate-university-research-2014-en.pdf (22.04.2015).

Yan Zhang C., 2013, The Rise of Glocal Education: ASEAN Countries, QS Top Universities, http:// www.topuniversities.com/where-to-study/region/asia/rise-glocal-education-asean-countries (10.03.2015).

\section{Internet}

[1] http://aanzfta.asean.org/ (15.11.2015).

[2] http://acts.ui.ac.id/ (15.11.2015).

[3] http://www.asean.org/asean/external-relations/asean-3/item/asean-plus-three-cooperation

[4] http://www.asean-qa.de/ (9.11.2015).

[5] http://www.aunsec.org/index.php (9.11.2015).

[6] http://www.aunsec.org/index.php (9.11.2015).

[7] http://www.rihed.seameo.org/ (9.11.2015).

[8] http://www.rihed.seameo.org/quality-assurance/ (9.11.2015).

[9] http://www.share-asean.eu/ (15.11.2015).

[10] http://www.uis.unesco.org/Education/Pages/international-student-flow-viz.aspx.

[11] http://www.uis.unesco.org/Pages/default.aspx (19.08.2015).

[12] https://www.insidehighered.com/blogs/globalhighered/towards-harmonization-higher-educationsoutheast-asia\#ixzz339fdDrY5/. 